\title{
Regenerated silica-based RNA purification columns to address the short supply of RNA purification kits for COVID-19 diagnosis
}

\author{
Jitendra K. Biswal ${ }^{1}$ (D) Rajeev Ranjan ${ }^{1} \cdot$ Shyam Singh Dahiya ${ }^{1} \cdot$ Smrutirekha Mallick $^{1} \cdot$ Jajati K. Mohapatra ${ }^{1}$
}

Received: 30 May 2021 / Accepted: 24 August 2021 / Published online: 12 September 2021

(c) The Author(s), under exclusive licence to Springer Nature B.V. 2021

\begin{abstract}
Background RT-qPCR technique is the current world-wide method used for the early detection of SARS-CoV2 RNA in the suspected clinical samples. Viral RNA extraction is the key pre-analytical step for SARS-CoV2 detection which often achieved using commercial RNA-extraction kits. However, due to the COVID-19 pandemic, bulk production and the supply chains for the commercial RNA-extraction kit have been seriously compromised. The shortage of commercial RNA-extraction kit is even more acute in developing country. Furthermore, use of one-off design RNA-columns can generate plastic wastes that have an environmental pollution effect.

Methods and results To address these issues, in this study, we used warm alkaline solution containing Triton X-100 for the complete removal of the residual SARS-CoV2 RNA from the used RNA-binding silica column. Columns regenerated using the alkaline solution have the viral RNA purification capability that is comparable to the fresh silica columns. We also demonstrated that RNA-binding silica columns can be regenerated and reused for a minimum of five-times.

Conclusions Therefore, the use of the RNA-column regeneration method may benefits several SARS-CoV2 diagnostic laboratories throughout the world by cutting down the requirement of commercial RNA-purification column.
\end{abstract}

Keywords SARS-CoV2 $\cdot$ COVID-19 $\cdot$ RT-qPCR $\cdot$ RNA-extraction $\cdot$ Regenerated RNA-purification column

\section{Introduction}

The coronavirus disease 2019 (COVID-19) pandemic which is caused by severe acute respiratory syndrome coronavirus-2 (SARS-CoV2) has emerged as a serious threat to the human health globally [1]. The elderly people and those with pre-existing medical conditions are prone to have severe or deadly COVID-19 infection [2], thereby leading to a high burden on global health care system. Detecting the presence of SARS-CoV2 genome and/or antigen is of extreme importance for the containment strategies aiming to reduce the spread of the virus $[3,4]$. However, due to several bottlenecks imposed by the cost involvement in timely and quality virus diagnosis, understanding and managing the COVID19 outbreak has remained a challenge for several countries world-wide [5].

Jitendra K. Biswal

jkubiswal@gmail.com

1 ICAR-International Centre for Foot-and-Mouth Disease, DFMD, Jatni, Khordha, Odisha, India
Early diagnosis of COVID-19 relies on the efficient detection of SARS-CoV2 genome using RT-qPCR [6-8]. Several RT-qPCR assays have been used for the virus diagnosis and novel technologies for the detection of the viral RNA are constantly evolving with time [9, 10]. All these nucleic acid recognition methods require an RNA-extraction step to isolate the SARS-CoV2 RNA before its detection. Therefore, the availability of RNA-extraction kits have become a serious limitation for COVID-19 diagnosis due to the world-wide demand-driven shortage of commercial RNAextraction kits [11]. This is particularly difficult in countries lacking suitable infrastructure and capacity to produce in bulk good-quality RNA extraction kit locally. Furthermore, the commercial RNA-extraction kits recommended for single-use are expensive, and they generate plastic wastes which have a negative implication on the environment [11]. Therefore, the objective of this study is to re-use the RNA purification columns, thereby curtailing the utilization of commercial RNA-extraction kits while not compromising the diagnosis of SARS-CoV2.

Silica-resin columns are the key ingredient in the commercial RNA-purification kits and the columns allow the 
recovery of high-quality RNA. However, because of the retention of substantial amount of nucleic acid in the silicamatrix even after the elution step, the columns can only be used once [12, 13]. Nevertheless, earlier study demonstrated that silica columns from commercial RNA extraction kits can be quickly regenerated and utilized for the isolation of high quality RNA without the risk of carry-over contamination [14]. Since, this method of regenerated RNApurification columns was not studied earlier for purification and subsequent use for RT-qPCR-based detection of viral genome, in our current endeavour, we applied the method of Tagliavia et al., (2010), for the detection of SARS-CoV2 genome through RT-qPCR without compromising the diagnostic efficiency and simultaneously precluding the chance of carry-over contamination from previous use.

\section{Materials and methods}

\section{Swab samples and RNA extraction}

Samples included in this study consisted of nasal and throat swab samples in viral transport medium (VTM) that has been sent to the ICAR-International Centre for FMD for the diagnosis of SARS-CoV2 virus through RT-qPCR following the guidelines of Indian Council of Medical Research (ICMR). For RNA extraction, $200 \mu \mathrm{l}$ of swab samples in VTM was mixed with $560 \mu \mathrm{l}$ of lysis buffer, and RNA was extracted using QIAamp Viral RNA Mini Kit (Qiagen) as per the manufacturer's instruction.

\section{SARS-CoV2 real-time reverse transcription PCR (RT-qPCR) analyses}

The extracted RNA samples were amplified with commercial SARS-CoV2 one-step multiplex RT-qPCR kit (Allplex 2019-nCoV kit). The Allplex 2019-nCoV kit (Allplex; Seegene, Seoul, Korea) targets the Envelop (E), RNA-dependant RNA-polymerase (RdRp) and nucleocapsid protein $(\mathrm{N})$ coding genes of SARS-CoV2. The kit uses bacteriophage MS2 as an exogenous internal control by spiking the internal control directly into the swab samples prior to RNA extraction [15]. The internal control was used to address the reliability of RNA-extraction procedure and any PCR-inhibition effects by the sample type. The results from the RT-qPCR assay were interpreted as positive when all target genes were detected together $(\mathrm{Ct}$ value $<40)$.

\section{Residual RNA elimination and regeneration of used RNA columns}

Elimination of residual RNA (decontamination) from the used columns was performed as per the procedure described earlier [14] with modification. The used QIAamp Viral Mini kit silica-columns were loaded with $600 \mu \mathrm{l}$ of pre-warmed $\left(80{ }^{\circ} \mathrm{C}\right)$ alkaline solution containing $0.25 \mathrm{M} \mathrm{NaOH}$ and $0.1 \%$ (v/v) Triton-X-100, the columns were incubated for $10 \mathrm{~min}$ at $37^{\circ} \mathrm{C}$, and subsequently centrifuged at $12,000 \mathrm{~g}$ for $3 \mathrm{~min}$. The alkaline solution treatment of used-columns was repeated by incubating the columns at $37^{\circ} \mathrm{C}$ for $20 \mathrm{~min}$. Then, the used-columns were incubated for $5 \mathrm{~min}$ at $37{ }^{\circ} \mathrm{C}$ with $600 \mu \mathrm{l}$ of $50 \mathrm{mM}$ sodium acetate buffer, $\mathrm{pH} 4.0$, and centrifuged at $12,000 \times \mathrm{g}$ for $3 \mathrm{~min}$. Afterwards, the RNAbinding silica columns were incubated for $5 \mathrm{~min}$ at roomtemperature with $600 \mu \mathrm{l}$ of RNase-free water and subsequently centrifuged at $12,000 \times g$ for $1 \mathrm{~min}$.

To evaluate the extent of elimination of the residual RNA bound to the columns from the first use, $40 \mu$ of elution buffer was added to the centre of each regenerated column, and the RNA remaining within the column was eluted by centrifugation and collected in a $1.5 \mathrm{ml}$ micro-centrifuge tube. The eluted solution was subsequently analysed by RTqPCR to determine the efficacy of elimination of residual RNA from the used RNA column.

Since SARS-CoV2 viral-RNA is potentially infectious in nature, all the plastic wastes and flow-through generated during the RNA-column regeneration procedure should be discarded into recommended disinfectants (e.g. 0.1\% Sodium hypochlorite solution).

\section{Statistical analysis}

Mean Ct values obtained through both the method of RNA extraction (fresh RNA column or regenerated RNA column) for each SARS-CoV2 target gene were analysed in pairwise comparisons using the paired Student's t-test. The analysis was performed using GraphPad Prism 8 software.

\section{Results \\ Elimination of residual SARS-CoV2 RNA from the used RNA-binding columns and regeneration for re-use}

To optimise the method of elimination of residual SARSCoV2 RNA and subsequent regeneration of used RNAbinding silica columns, fresh columns from commercial RNA-extraction kit (QIAamp Viral RNA mini kit,Qiagen) were initially used to extract the viral-RNA from suspected COVID-19 swab samples. The residual SARS-CoV2 viral RNA in the used columns was eliminated using the methodology described in the "Residual RNA elimination and regeneration of used RNA columns" section. To evaluate the efficacy of elimination, any residual RNA was recovered by $40 \mu$ elution and the eluate was used as template 
in SARS-CoV2 specific RT-qPCR assays. The RT-qPCR assays showed that the methodology used in our study has been effective in the complete elimination of residual viral RNA from the used RNA-binding silica column (Fig. 1). Furthermore, 44 number of used RNA-binding silica columns from known COVID-19 positive sample-extractions were regenerated and analysed by RT-qPCR for the presence of any residual SARS-CoV2 RNA. The analyses suggested a complete removal of residual RNAfrom the used RNAbinding silica columns after the process of RNA-decontamination and column-regeneration (Table 1).

\section{Comparative efficiency of the regenerated and fresh RNA-binding columns for viral RNA purification}

To compare the RNA-extraction ability of used-regenerated columns with that of the fresh-RNA binding columns, 44 clinical samples with various $\mathrm{Ct}$ values were analysed. Viral RNA was extracted using QIAamp Viral RNA min kit, and the Taqman probe-based RT-qPCR assay was carried using the Allplex 2019-nCoV kit. We analysed the efficiency between the fresh and used-regenerated RNA-binding columns in three different groups of positive samples: samples with low $\mathrm{Ct}$ value $(\mathrm{Ct}<25 ; n=20)$, samples with moderate $\mathrm{Ct}$ value $(\mathrm{Ct}=26$ to $34 ; n=14)$, and samples with high $\mathrm{Ct}$ value $(\mathrm{Ct}=35$ to $40 ; n=10)$. The detailed results for these 44 samples are shown in Table 1. The mean Ct values obtained through both the methods for each target gene of SARSCoV2 were also analysed in pair-wisecomparison (Fig. 2). As illustrated in Fig. 2, there were no significant differences in $\mathrm{Ct}$ values for $\mathrm{RdRp}, \mathrm{N}$ and $\mathrm{E}$ genes obtained using either fresh RNA columns or used-regenerated columns. However, for some samples with high $\mathrm{Ct}$ values, SARS-CoV2 target genes could not be detected using the RNA extracted through the regenerated RNA-columns (Table 1).

\section{Use-regeneration-reuse of RNA-binding columns for a minimum of five-times}

To determine whether the RNA-binding disposable silica columns from the viral RNA extraction kit could be repeatedly regenerated and reused for RNA purification, SARSCoV2 RNA was extracted using a fresh QIAamp Viral RNA mini kit column (Qiagen) and analysed for the presence of viral genes by RT-qPCR. The same used column was repeatedly regenerated and used for the extraction

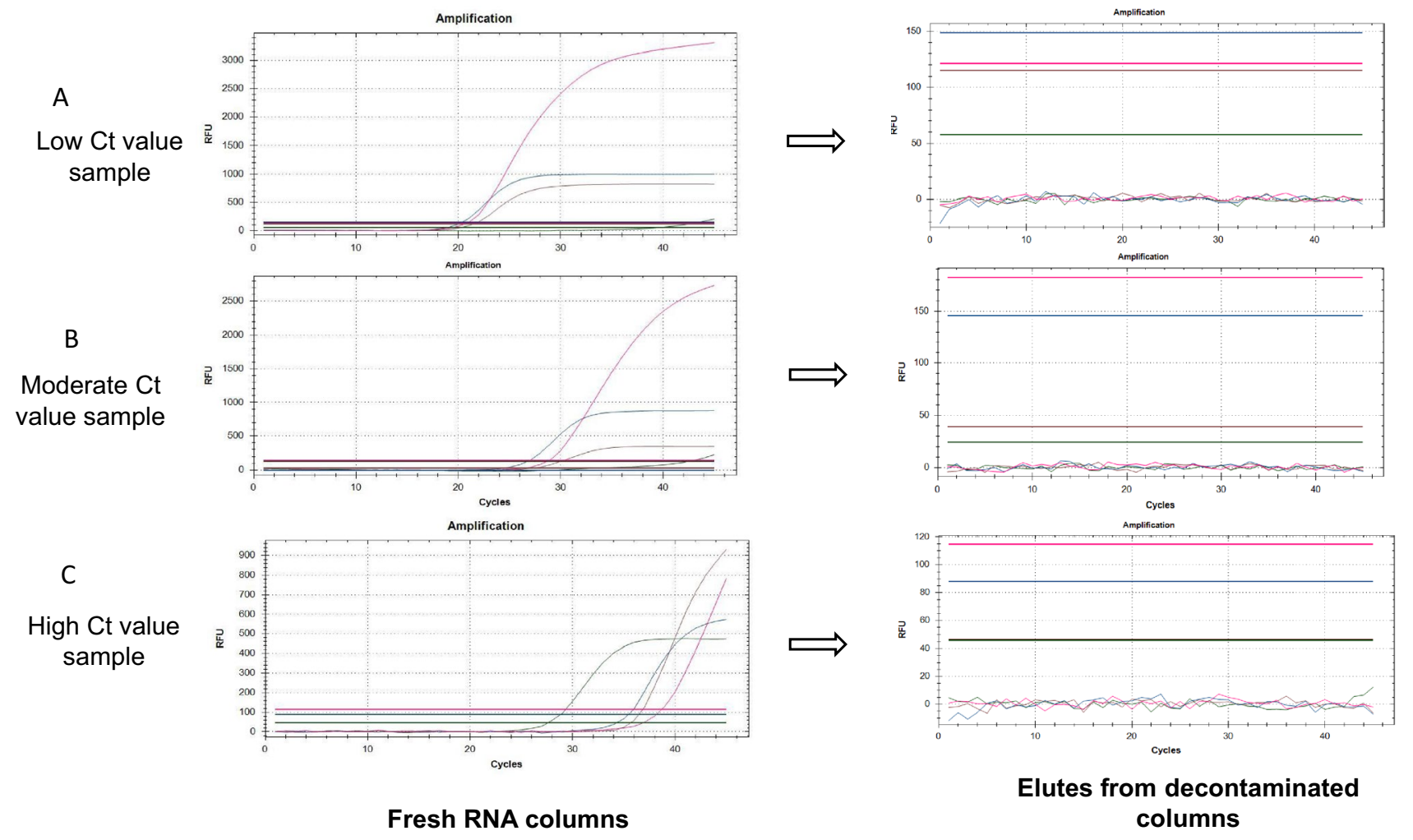

Fig. 1 Elimination of residual SARS-CoV2 RNA from the used QIAamp Viral RNA mini kit column by heated alkaline solution treatment. RT-qPCR analysis showed the complete removal of residual viral RNA in the elute from the used RNA-binding columns that has been treated with heated alkaline solution as per the methodology described in "Materials and methods" section. Columns used for RNA-extraction of SARS-CoV2 positive samples with low Ct-value (A), moderate $\mathrm{Ct}$ value $(\mathbf{B})$ and high $\mathrm{Ct}$ value $(\mathbf{C})$ 
Table 1 Comparative Ct value data for SARS-CoV2 RNA extracted using the fresh RNA-binding silica column (QIAamp Viral RNA Mini Kit) and regenerated RNA-column for the known COVID-19 swab samples $(n=44)$

\begin{tabular}{|c|c|c|c|c|c|c|c|c|c|c|c|c|c|}
\hline & \multirow[t]{2}{*}{ Sample } & \multicolumn{4}{|c|}{ RNA extracted using fresh column } & \multicolumn{4}{|c|}{$\begin{array}{l}\text { Residual RNA in regener- } \\
\text { ated column }\end{array}$} & \multicolumn{4}{|c|}{$\begin{array}{l}\text { RNA extracted using regenerated } \\
\text { column }\end{array}$} \\
\hline & & $\mathrm{RdRp}$ & E & $\mathrm{N}$ & IC & $\mathrm{RdRp}$ & E & $\mathrm{N}$ & IC & $\mathrm{RdRp}$ & E & $\mathrm{N}$ & IC \\
\hline \multirow[t]{20}{*}{ Low $\mathrm{Ct}$ value samples } & S1 & 17.91 & 16.15 & 15.06 & 38.43 & nd & nd & nd & nd & 19.10 & 17.52 & 18.21 & 38.60 \\
\hline & S2 & 15.87 & 17.32 & 19.37 & 36.62 & nd & nd & nd & nd & 14.74 & 15.97 & 15.65 & 40.20 \\
\hline & S3 & 19.26 & 19.93 & 15.54 & 33.72 & nd & nd & nd & nd & 18.11 & 19.10 & 18.65 & 38.65 \\
\hline & S4 & 15.43 & 15.13 & 14.69 & 38.12 & nd & nd & nd & nd & 15.21 & 15.91 & 17.73 & 35.56 \\
\hline & S5 & 17.32 & 19.37 & 15.87 & 36.62 & nd & nd & nd & nd & 19.10 & 17.96 & 17.39 & 38.32 \\
\hline & S6 & 19.26 & 15.23 & 16.82 & 36.98 & nd & nd & nd & nd & 15.23 & 18.50 & 16.88 & 39.10 \\
\hline & S7 & 18.81 & 17.95 & 15.64 & 39.19 & nd & nd & nd & nd & 16.21 & 15.58 & 15.87 & 36.45 \\
\hline & S8 & 18.83 & 18.94 & 16.13 & 30.07 & nd & nd & nd & nd & 14.16 & 17.87 & 14.32 & 40.24 \\
\hline & S9 & 19.23 & 18.88 & 19.49 & 36.32 & nd & nd & nd & nd & 19.88 & 16.42 & 17.07 & 38.90 \\
\hline & S10 & 18.52 & 18.06 & 14.42 & 30.78 & nd & nd & nd & nd & 16.88 & 16.12 & 18.10 & 35.56 \\
\hline & S11 & 19.55 & 17.92 & 19.16 & 37.12 & nd & nd & nd & nd & 18.91 & 17.87 & 17.10 & 39.56 \\
\hline & $\mathrm{S} 12$ & 23.95 & 21.40 & 23.00 & 36.72 & nd & nd & nd & nd & 24.12 & 21.85 & 20.33 & 38.18 \\
\hline & $\mathrm{S} 13$ & 24.09 & 20.94 & 22.31 & 33.94 & nd & nd & nd & nd & 26.15 & 22.41 & 24.22 & 37.99 \\
\hline & $\mathrm{S} 14$ & 24.43 & 21.83 & 23.93 & 40.27 & nd & nd & nd & nd & 24.14 & 21.35 & 24.32 & 36.66 \\
\hline & S15 & 22.29 & 20.11 & 22.12 & 37.47 & nd & nd & nd & nd & 20.42 & 18.87 & 19.39 & 38.81 \\
\hline & S16 & 20.23 & 20.64 & 18.88 & 38.90 & nd & nd & nd & nd & 18.10 & 16.60 & 18.34 & 36.92 \\
\hline & S17 & 24.51 & 22.05 & 23.05 & 36.72 & nd & nd & nd & nd & 26.66 & 23.06 & 24.03 & 33.08 \\
\hline & $\mathrm{S} 18$ & 23.15 & 22.41 & 24.22 & 35.99 & nd & nd & nd & nd & 24.37 & 24.64 & 24.84 & 32.61 \\
\hline & S19 & 23.14 & 21.35 & 22.32 & 36.66 & nd & nd & nd & nd & 24.32 & 21.74 & 23.35 & 38.20 \\
\hline & S20 & 24.26 & 22.72 & 24.16 & 32.29 & nd & nd & nd & nd & 22.10 & 24.59 & 23.48 & 33.05 \\
\hline \multirow[t]{14}{*}{ Moderate $\mathrm{Ct}$ value samples } & S21 & 30.60 & 27.90 & 29.84 & 26.69 & nd & nd & nd & nd & 32.49 & 29.33 & 29.08 & 32.98 \\
\hline & S22 & 31.10 & 28.34 & 29.67 & 25.82 & nd & nd & nd & nd & 32.08 & 31.58 & 30.06 & 32.37 \\
\hline & S23 & 33.56 & 33.86 & 33.69 & 31.56 & nd & nd & nd & nd & 34.62 & 32.59 & 32.14 & 27.33 \\
\hline & S24 & 29.47 & 28.19 & 28.04 & 26.60 & nd & nd & nd & nd & 29.39 & 27.34 & 26.80 & 30.12 \\
\hline & S25 & 26.95 & 21.40 & 23.00 & 36.72 & nd & nd & nd & nd & 28.15 & 22.41 & 24.22 & 40.91 \\
\hline & S26 & 29.39 & 26.80 & 27.34 & 29.18 & nd & nd & nd & nd & 30.18 & 28.14 & 28.80 & 31.61 \\
\hline & S27 & 31.20 & 28.96 & 28.35 & 29.03 & nd & nd & nd & nd & 29.63 & 26.87 & 27.01 & 31.01 \\
\hline & S28 & 26.45 & 25.91 & 29.69 & 28.53 & nd & nd & nd & nd & 24.43 & 23.95 & 28.83 & 30.12 \\
\hline & S29 & 31.57 & 29.64 & 32.03 & 32.66 & nd & nd & nd & nd & 33.26 & 28.89 & 29.35 & 31.61 \\
\hline & $\mathrm{S} 30$ & 26.32 & 21.74 & 23.35 & 38.20 & nd & nd & nd & nd & 24.14 & 21.35 & 22.32 & 36.66 \\
\hline & S31 & 26.08 & 27.61 & 28.51 & 35.95 & nd & nd & nd & nd & 29.54 & 27.99 & 26.31 & 31.30 \\
\hline & S32 & 28.10 & 25.51 & 27.03 & 36.61 & nd & nd & nd & nd & 30.18 & 27.11 & 28.14 & 38.43 \\
\hline & S33 & 33.29 & 30.68 & 31.24 & 32.90 & nd & nd & nd & nd & 32.69 & 30.33 & 32.55 & 32.32 \\
\hline & S34 & 28.80 & 28.09 & 27.17 & 42.37 & nd & nd & nd & nd & 26.08 & 29.41 & 29.17 & 39.93 \\
\hline \multirow[t]{10}{*}{ High Ct value samples } & S35 & 38.65 & 35.15 & 38.62 & 32.49 & nd & nd & nd & nd & 34.14 & 31.69 & 33.78 & 31.09 \\
\hline & S36 & 36.32 & 39.29 & 37.89 & 32.87 & nd & nd & nd & nd & 40.02 & nd & 36.46 & 29.10 \\
\hline & S37 & 37.06 & 38.42 & 41.43 & 27.30 & nd & nd & nd & nd & nd & nd & nd & 28.65 \\
\hline & $\mathrm{S} 38$ & 36.96 & 37.11 & 38.30 & 28.49 & nd & nd & nd & nd & 30.02 & 35.35 & 35.87 & 27.10 \\
\hline & S39 & 38.85 & 37.47 & 33.41 & 30.41 & nd & nd & nd & nd & 39.61 & 41.20 & 37.35 & 29.91 \\
\hline & $\mathrm{S} 40$ & 36.19 & 36.02 & 36.99 & 32.44 & nd & nd & nd & nd & 32.02 & 30.48 & 31.91 & 29.47 \\
\hline & S41 & 38.68 & 35.43 & 35.65 & 29.19 & nd & nd & nd & nd & 40.19 & 36.66 & 39.02 & 26.43 \\
\hline & S42 & 38.37 & 37.82 & 38.57 & 28.35 & nd & nd & nd & nd & nd & 40.0 & nd & 25.56 \\
\hline & S43 & 37.15 & 36.02 & 35.68 & 30.00 & nd & nd & nd & nd & 31.92 & 33.45 & 33.76 & 29.36 \\
\hline & S44 & 36.71 & 33.58 & 34.21 & 32.27 & nd & nd & nd & nd & 40.10 & 35.43 & 36.73 & 31.10 \\
\hline
\end{tabular}


A

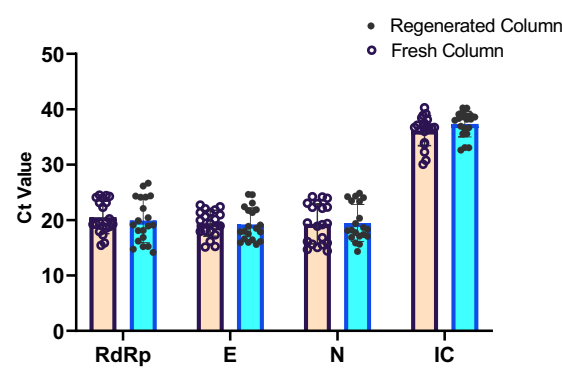

Low Ct value samples
B

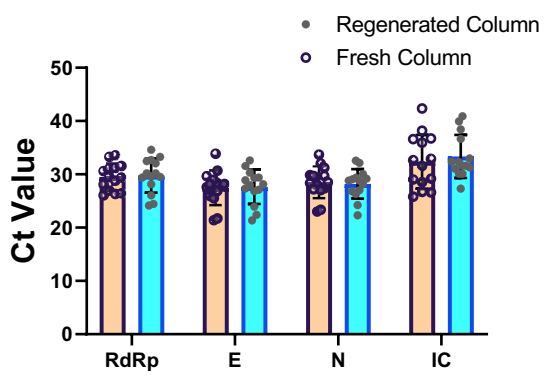

Moderate Ct value samples
C

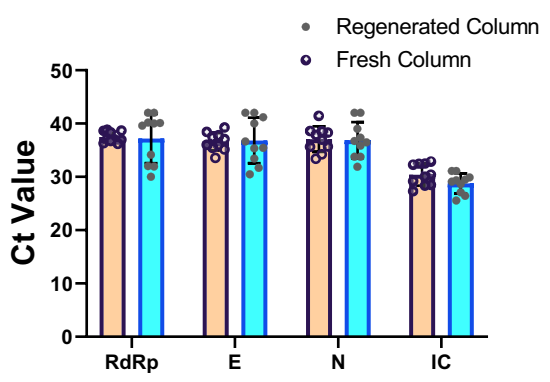

High Ct value samples
Fig. 2 Regenerated Viral-RNA purification kit columns have a comparable capacity for SARS-CoV2 RNA purification as the fresh columns. Bars represent the mean \pm standard deviation $\mathrm{Ct}$ values for each SARS-CoV2 RT-qPCR target genes RdRp, E, N, and IC, for swab samples with $\mathrm{Ct}$ value $\leq 25(\mathbf{A}), \mathrm{Ct}$ value $=25-35(\mathbf{B})$, and $\mathrm{Ct}$ value $=36-40(\mathbf{C})$. Each dot represents one sample. Pairwise comparisons of mean $\mathrm{Ct}$ values for each SARS-CoV2 target gene were

of SARS-CoV2 RNA from the above known COVID-19 positive swab sample for four additional times. The concentration of viral RNA after each round was determined through SARS-CoV2 RT-qPCR. Figure 3 illustrated that done using a two-tailed paired Student's t-test, with a confidence level of $95 \%$. For low $\mathrm{Ct}$ value samples $\mathrm{p}$ value for $\mathrm{RdRp}, \mathrm{E}$ and $\mathrm{N}$ genes were $0.18,0.59$ and 0.75 respectively, for moderate $\mathrm{Ct}$ value samples $\mathrm{p}$ value for RdRp, E and $\mathrm{N}$ genes were $0.57,0.65$ and 0.47 respectively, and for high $\mathrm{Ct}$ value samples $\mathrm{p}$ value for RdRp, $\mathrm{E}$ and $\mathrm{N}$ genes were $0.84,0.85$ and 0.86 respectively

the RNA-binding silica columns regenerated for the fourth time exhibited a comparable viral-RNA yield as the fresh column. Therefore, the disposable viral RNA extraction
A

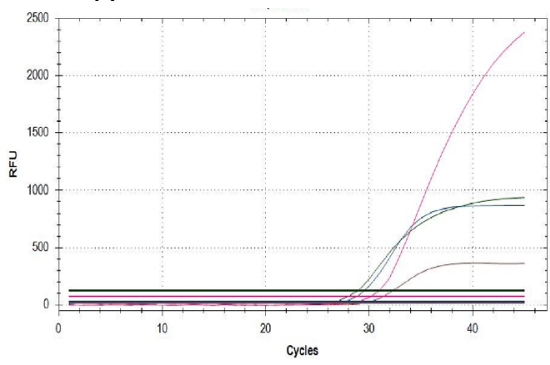

D

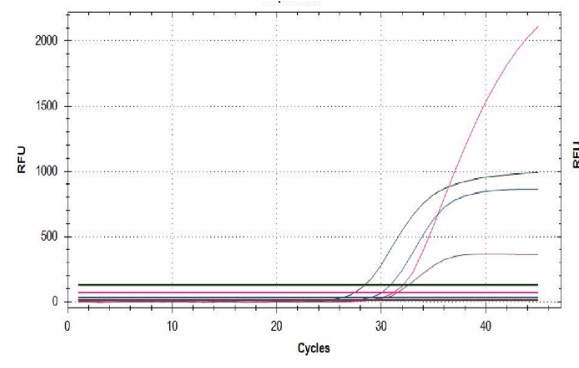

B

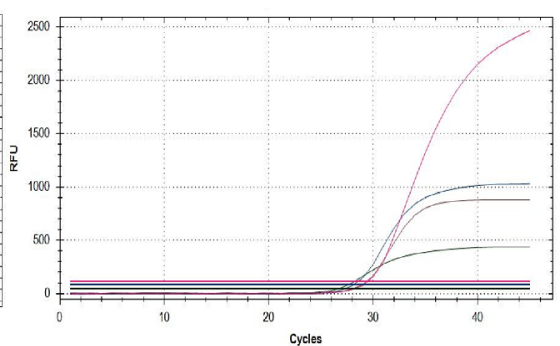

$E$

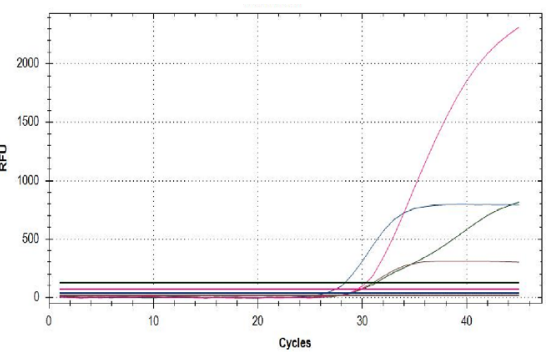

C

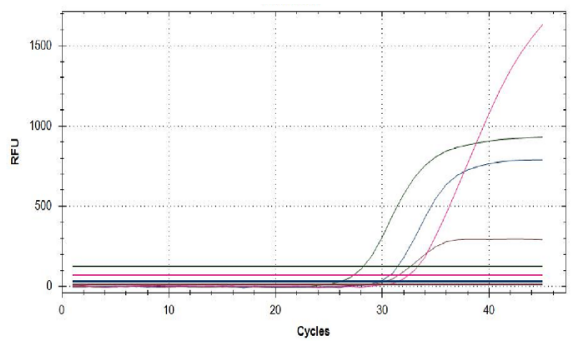

F

- Fresh Column $\circ$ 1st $\odot$ 2nd $\odot 3 r d \quad 4$ th

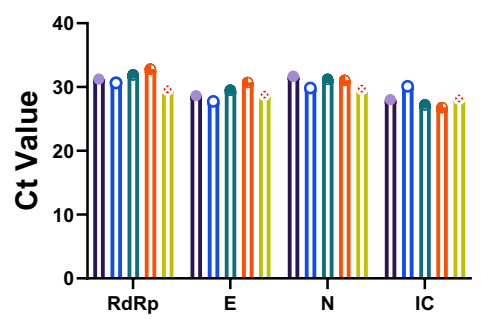

Fig. 3 RNA-binding silica columns can be repeatedly regenerated and reused for a minimum of five cycles. RNA was extracted from the SARS-CoV2 suspected swab samples using fresh silica column and analysed for the presence of viral genes by multiplex RT-qPCR (A). The same column was regenerated and reused for extraction of viral
RNA from the above known COVID-19 positive samples for four more times $(\mathbf{B}-\mathbf{E})$. RT-qPCR analyses suggested that RNA-binding silica columns regenerated for the fourth time exhibited a comparable viral-RNA yield as the fresh column $(\mathbf{F})$ 
column could be regenerated and reused for a minimum of five cycles without hampering the RNA-binding ability.

\section{Discussion}

RNA binding silica columns in the RNA-extraction kits allow the recovery of high-quality RNA without any organic extraction step. However, the major disadvantage of silica column-based RNA-extraction kit is the cost and their availability during world-wide infectious disease pandemic as in the case of COVID-19. Therefore, techniques need to be developed and evaluated for the recycling of RNA-binding silica columns in order to reduce the cost of RNA extraction and to ensure continuity of diagnostic service during short supply of kits in COVID-19 clinical diagnostic laboratories.

However, the challenge in the viral RNA-binding silica columns regeneration procedure is not only the complete removal of viral RNA, but also the requirement of a quick protocol making the used columns ready again for the purification of good quality viral RNA without compromising the sensitivity and specificity of the viral diagnostic assay. Owing to the presence of 2' hydroxyl group (OH), RNA is very unstable in alkaline condition as compared to DNA [16]. The 2'-OH group of RNA becomes de-protonated under high-alkaline condition leading to nucleophilic attack on the $5^{\prime}-\mathrm{PO}_{4}$ group of the adjacent nucleotide, resulting in the cleavage of the phospho-pentose backbone of RNA. Therefore, alkaline $\mathrm{pH}$ solution along with heat treatment has been used earlier to selectively degrade RNA in RNA-DNA hybrids $[17,18]$.So, the silica column-bound residual RNA in the used columns can be effectively hydrolysed and removed by heated alkaline solution. Furthermore, alkaline solution can inactivate RNase, leaving the used silica columns both RNA and RNase-free [19].

Earlier through agarose-gel electrophoresis-based PCR assay it has been shown that disposable columns from RNA-extraction kit can be decontaminated using heated alkaline solution [14]. However, until now, decontaminated and regenerated RNA-binding silica column has not been used for virus detection assays through the TaqMan probebased RT-qPCR assay. Since, RT-qPCR PCR assay is more sensitive to detect the PCR-amplicons as compared to the agarose-gel electrophoresis-based PCR; we had modified the earlier procedure for purification of used-RNA columns, so that the complete degradation of left-over RNA from earlier run could be possible. In addition, during the initial development and validation of decontamination of RNA columns as per the earlier reported procedures [14], we had detected left-over RNA for certain swab samples with low Ct values (Ct value $<20$ ), however, the observations was not uniform for all the clinical samples with low $\mathrm{Ct}$ values (data not shown). Nevertheless, to ensure complete degradation of left-over RNA we had modified the earlier reported protocol.

In our study, through real time RT-PCR assay we confirmed that regenerated disposable RNA columns can be used for the detection of COVID-19 viral genome without any risk of carryover contaminated viral RNA from previous experiment. Furthermore, no significant difference in Ct-values for the SARS-CoV2 target genes was observed using the viral RNA either from the regenerated or fresh RNA-binding columns. However, it is worth mentioning that fluctuation has been observed in the $\mathrm{Ct}$ value between the two methods of RNA extraction for the samples with viral load around the cut-off value of the RT-qPCR assay $(\mathrm{Ct}=40)$. Although, samples with higher $\mathrm{Ct}$ value may be associated with low viral load and low risk of infection transmission [20, 21], a swab-sample collected at a single time point does not provide details about the trajectory of SARS-CoV2 illness status [22]. Therefore, the regenerated RNA-columns may only be used for urgent conditions during the short supply of RNA-purification kit. In our study, we also established that the used disposable RNA-binding columns could be stripped of bound-RNA, regenerated, and re-used at least for five-times without compromising either the quality of viral RNA or the binding properties of silica columns. In our study, the method of regeneration and re-use of used RNA-purification columns for COVID-19 diagnosis was also extended for RNA-binding silica columns from two commercial sources (HiPurA ${ }^{\mathrm{TM}}$ Viral RNA Purification Kit, HIMEDIA, and PureLink RNA Mini Kit, Invitrogen, Thermo). The results were comparable to the columns from the QIAamp Viral RNA Mini Kit (data not shown). Therefore, the methodology adopted in this manuscript can be applied to any used RNA-purification column from other commercial sources apart from Qiagen.

In conclusion, we showed that the used disposable viralRNA binding columns can be decontaminated using warm alkaline buffer and regenerated using acidic sodium acetate buffer. The regeneration process could be completed in approximately $25 \mathrm{~min}$ for a set of 10 -columns. The treatment process does not impair the column's RNA-binding efficacy, thereby, making it possible to use the same column for COVID-19 diagnosis for at least five times. The use of regenerated RNA-binding silica columns can reduce the production of laboratory plastic-wastes and could help to save fund and ensure continuity of diagnostic service during the COVID-19 pandemic.

Acknowledgements Indian Council of Agricultural Research (ICAR) provided necessary facilities to carry out this work.

Author contributions Study concept and design was done by JKB. Experiments, data collection and analyses were performed by JKB, RR, SSD, SM, \& JKM. The first draft of the manuscript was written by JKB 
and all authors commented on the previous version of the manuscript. All the authors read and approved the final manuscript.

\section{Declarations}

Conflict of interest The authors declare no conflict of interest.

Ethical approval The study described in this manuscript was conducted as part of the diagnosis of COVID-19 suspected human swab samples submitted at the authors' laboratory. Since there was no disclosure regarding the names or the physical, economic, cultural, and social status of the patients, individual patient consent or ethical approval is not required.

Informed consent Authors approve for submitting the publication.

Research involved in human or animal rights No experiment was conducted on animals in this study.

\section{References}

1. Dao Thi VL, Herbst K, Boerner K, Meurer M, Kremer LP, Kirrmaier D, Freistaedter A, Papagiannidis D, Galmozzi C, Stanifer ML, Boulant S, Klein S, Chlanda P, Khalid D, Barreto Miranda I, Schnitzler P, Krausslich HG, Knop M, Anders S (2020) A colorimetric RT-LAMP assay and LAMP-sequencing for detecting SARS-CoV-2 RNA in clinical samples. Sci Transl Med. https:// doi.org/10.1126/scitranslmed.abc7075

2. Phua J, Weng L, Ling L, Egi M, Lim CM, Divatia JV, Shrestha BR, Arabi YM, Ng J, Gomersall CD, Nishimura M, Koh Y, Du B, Asian Critical Care Clinical Trials G (2020) Intensive care management of coronavirus disease 2019 (COVID-19): challenges and recommendations. Lancet Respir Med 8:506-517

3. Cheng VCC, Wong SC, To KKW, Ho PL, Yuen KY (2020) Preparedness and proactive infection control measures against the emerging novel coronavirus in China. J Hosp Infect 104:254-255

4. Peto J (2020) Covid-19 mass testing facilities could end the epidemic rapidly. BMJ 368:m1163

5. Chu AW, Chan WM, Ip JD, Yip CC, Chan JF, Yuen KY, To KK (2020) Evaluation of simple nucleic acid extraction methods for the detection of SARS-CoV-2 in nasopharyngeal and saliva specimens during global shortage of extraction kits. J Clin Virol 129:104519

6. Chu DKW, Pan Y, Cheng SMS, Hui KPY, Krishnan P, Liu Y, Ng DYM, Wan CKC, Yang P, Wang Q, Peiris M, Poon LLM (2020) Molecular diagnosis of a novel coronavirus (2019-nCoV) causing an outbreak of pneumonia. Clin Chem 66:549-555

7. Corman VM, Landt O, Kaiser M, Molenkamp R, Meijer A, Chu DK, Bleicker T, Brunink S, Schneider J, Schmidt ML, Mulders DG, Haagmans BL, van der Veer B, van den Brink S, Wijsman L, Goderski G, Romette JL, Ellis J, Zambon M, Peiris M, Goossens H, Reusken C, Koopmans MP, Drosten C (2020) Detection of 2019 novel coronavirus (2019-nCoV) by real-time RT-PCR. Euro Surveill 25:2000045

8. Huang C, Wang Y, Li X, Ren L, Zhao J, Hu Y, Zhang L, Fan G, Xu J, Gu X, Cheng Z, Yu T, Xia J, Wei Y, Wu W, Xie X, Yin W, Li H, Liu M, Xiao Y, Gao H, Guo L, Xie J, Wang G, Jiang R, Gao Z, Jin Q, Wang J, Cao B (2020) Clinical features of patients infected with 2019 novel coronavirus in Wuhan, China. Lancet 395:497-506
9. Esbin MN, Whitney ON, Chong S, Maurer A, Darzacq X, Tjian R (2020) Overcoming the bottleneck to widespread testing: a rapid review of nucleic acid testing approaches for COVID-19 detection. RNA 26:771-783

10. Jayamohan H, Lambert CJ, Sant HJ, Jafek A, Patel D, Feng H, Beeman M, Mahmood T, Nze U, Gale BK (2020) SARS-CoV-2 pandemic: a review of molecular diagnostic tools including sample collection and commercial response with associated advantages and limitations. Anal Bioanal Chem 413:49-71

11. Wozniak A, Cerda A, Ibarra-Henriquez C, Sebastian V, Armijo G, Lamig L, Miranda C, Lagos M, Solari S, Guzman AM, Quiroga T, Hitschfeld S, Riveras E, Ferres M, Gutierrez RA, Garcia P (2020) A simple RNA preparation method for SARS-CoV-2 detection by RT-qPCR. Sci Rep 10:16608

12. Siddappa NB, Avinash A, Venkatramanan M, Ranga U (2007) Regeneration of commercial nucleic acid extraction columns without the risk of carryover contamination. Biotechniques 42(186):188-192

13. Zhou Y, Zhang Y, He W, Wang J, Peng F, Huang L, Zhao S, Deng W (2018) Rapid regeneration and reuse of silica columns from PCR purification and gel extraction kits. Sci Rep 8:12870

14. Nicosia A, Tagliavia M, Costa S (2010) Regeneration of total RNA purification silica-based columns. Biomed Chromatogr 24:1263-1264

15. Hur KH, Park K, Lim Y, Jeong YS, Sung H, Kim MN (2020) Evaluation of four commercial kits for SARS-CoV-2 real-time reverse-transcription polymerase chain reaction approved by emergency-use-authorization in Korea. Front Med 7:521

16. Satoh K, Inoue Y (1969) Ion-exchangechrmtography of a dinucleotide preparation from controlled alkaline hydrolysis of ribonucleic acids. Biochem J 114:271-277

17. Hu Z, Troester M, Perou CM (2005) High reproducibility using sodium hydroxide-stripped long oligonucleotide DNA microarrays. Biotechniques 38:121-124

18. Mauger F, Bauer K, Calloway CD, Semhoun J, Nishimoto T, Myers TW, Gelfand DH, Gut IG (2007) DNA sequencing by MALDI-TOF MS using alkali cleavage of RNA/DNA chimeras. Nucleic Acids Res 35:e62

19. Rabe BA, Cepko C (2020) SARS-CoV-2 detection using isothermal amplification and a rapid, inexpensive protocol for sample inactivation and purification. Proc Natl Acad Sci USA 117:24450-24458

20. La Scola B, Le Bideau M, Andreani J, Hoang VT, Grimaldier C, Colson P, Gautret P, Raoult D (2020) Viral RNA load as determined by cell culture as a management tool for discharge of SARS-CoV-2 patients from infectious disease wards. Eur J Clin Microbiol Infect Dis 39:1059-1061. https://doi.org/10.1007/ s10096-020-03913-9

21. Skok K, Stelzl E, Trauner M, Kessler HH, Lax SF (2021) Postmortem viral dynamics and tropism in COVID-19 patients in correlation with organ damage. Virchows Arch 478:343-353. https:// doi.org/10.1007/s00428-020-02903-8

22. Rao SN, Manissero D, Steele VR, Pareja JA (2020) Narrative systematic review of the clinical utility of cycle threshold values in the context of COVID-19. Infect Dis Ther 9:573-586. https:// doi.org/10.1007/s40121-020-00324-3

Publisher's Note Springer Nature remains neutral with regard to jurisdictional claims in published maps and institutional affiliations. 